\title{
Strengths of early physical rehabilitation programs in surgical breast cancer patients: results of a randomized control study
}

\author{
Antonio Testa ${ }^{1 *}$, C lannace ${ }^{2}$, L Di Libero ${ }^{2}$, F Caracciolo ${ }^{2}$ \\ From International Conference for Healthcare and Medical Students 2012 \\ Dublin, Ireland. 2-3 November 2012
}

\section{Background}

In the immediate post-operative period, breast cancer patients can face many problems including functional limitation of the shoulder, pain and depression. Aim of this study, comparing 2 groups of patients, one that underwent to a physical rehabilitation program (PRP) and one as a control group, is to evaluate: functional improvements of shoulder mobility, analgesic effect of PRP, improvements and/or worsening of quality of life (QoL).

\section{Methods}

Seventy women planned for axillary dissection were included in this study and randomly assigned to treated (TG) or control group (CG). Patients of the TG, underwent first, to assisted cautious mobilization of hand, wrist and elbow and after drainage removal, to twenty physiotherapy sessions. CG did not underwent to physical rehabilitation treatment. Participants were evaluated before surgery and postoperatively at fifth day, first, sixth and twelfth month. Shoulder mobility was estimated through the use of a Myrin goniometer. VAS scale was used to estimate pain perceived. EORTC QLQ-30 and EORTC QLQ-BR23 1 questionnaires were used to assess QoL. ANCOVA test was utilized to compare outcomes between groups regarding joint mobility and pain perceived using baseline data as covariates. Two tailed t-Tests were used for the statistical analysis within groups. MannWhitney non-parametric test was used to analyze QoL outcomes.

\section{Results}

Statistically significant difference $(\mathrm{p}<0.01)$ between the two groups, in flexion and abduction movements, was reported. Within group analysis, from preoperative period to 12th month, showed absence of statistically significant difference in the TG, while at same time proved statistically significant difference $(\mathrm{p}<0.05)$ in the CG regarding flexion, abduction and internal rotation movements. This evidence that TG regained normal function at 1 year after rehabilitation treatment while CG was unable to do so for flexion, abduction and internal rotation movements. Statistically significant differences $(\mathrm{p}<0.001)$ were observed in terms of pain perception starting from the first month. Results analysis showed effectiveness of rehabilitation treatment in improving patient's quality of life.

\section{Conclusions}

Postoperative early PRP in breast cancer patients surgically treated with axillary dissection improves significantly the glenohumeral joint mobility, permitting the patients to regain normal shoulder function, reduces pain and widely improves QoL. Authors recognise it as a very intensive rehabilitation programme. They still believe, however, that early rehabilitation should be part of the standard treatment in patient with breast cancer following axillary dissection having a key role in patient's physical and psycho-social recovery.



Published: 30 January 2013

\footnotetext{
* Correspondence: mdantoniotesta@gmail.com

${ }^{1}$ Victor Babeş, University of Medicine and Pharmacy, Timişoara, Romania

Full list of author information is available at the end of the article
}

(c) 2013 Testa et al; licensee BioMed Central Ltd. This is an Open Access article distributed under the terms of the Creative Commons Attribution License (http://creativecommons.org/licenses/by/2.0), which permits unrestricted use, distribution, and reproduction in any medium, provided the original work is properly cited. 


\section{Reference}

1. Fayers P, Aaronson N, Bjordal K, Groenvold M, Curran D, Bottomley A, EORTC Quality of Life Group: The EORTC QLQ-C30 Scoring Manual. European Organisation for Research and Treatment of Cancer; 32001.

doi:10.1186/1753-6561-7-S1-05

Cite this article as: Testa et al:: Strengths of early physical rehabilitation programs in surgical breast cancer patients: results of a randomized control study. BMC Proceedings 2013 7(Suppl 1):05.

Submit your next manuscript to BioMed Central and take full advantage of:

- Convenient online submission

- Thorough peer review

- No space constraints or color figure charges

- Immediate publication on acceptance

- Inclusion in PubMed, CAS, Scopus and Google Scholar

- Research which is freely available for redistribution

Submit your manuscript at www.biomedcentral.com/submit 